\title{
Lea da Cruz Fagundes
}

A homenageada desta edição, Lea da Cruz Fagundes, é uma mulher que sempre esteve à frente de seu tempo, tornando-se protagonista da educação inovadora no Brasil. Psicóloga, pedagoga e professora há mais de 60 anos, Léa Fagundes foi pioneira na aplicação das tecnologias aos processos educacionais. Por acreditar que as tecnologias digitais auxiliam na aprendizagem, defende o uso da informática educacional e o da inserção do ensino na cultura digital.

Graduou-se em Pedagogia e Psicologia, e tornou-se Mestre em Educação pela Universidade Federal do Rio Grande do Sul. Em 1986, recebeu o título de Doutora em Ciências - Psicologia pelo Instituto de Psicologia da Universidade de São Paulo. Atualmente, Léa é professora titular aposentada da Universidade Federal do Rio Grande do Sul, docente convidada no Mestrado em Psicologia Social e Institucional e no programa de Pós-Graduação em Informática na Educação dessa instituição.

Fundadora e coordenadora do primeiro grupo de pesquisas brasileiro a estudar o desenvolvimento cognitivo infantil, o LEC - Laboratório de Estudos Cognitivos da Universidade Federal de do Rio Grande do Sul, dedica-se há mais de 20 anos ao estudo da informática na educação.

Desde a implantação do Programa Nacional de Informática na Educação (Proinfo), em 1994, integra o Comitê Assessor em Informática e Educação do Ministério da Educação e coordena o projeto Um Computador por Aluno (UCA) na Região Sul. Além disso, preside a Fundação Pensamento Digital, Organização não governamental que atua no processo de inclusão digital de comunidades economicamente desfavorecidas.

Léa Fagundes é considerada uma das maiores especialistas da Améria Latina em Jean Piaget, e presta consultorias internacionais sobre o uso das tecnologias da informação e comunicação (TIC) na educação e na formação de professores desde a década de 90 . Baseada na teoria desse epistemólogo, comprovou, em suas pesquisas, que toda criança é capaz de aprender.

Recebeu prêmios internacionais em reconhecimento à sua contribuição para a melhoria da qualidade da educação. Em 2006, recebeu um Diploma de Reconhecimento da Organização das Nações Unidas para a Educação, a Ciência e Cultura (Unesco), na categoria Informática e Comunicação, um reconhecimento merecido pelo seu pioneirismo no uso da informática nas escolas públicas do Brasil. Em 2010, foi a vez das Organizações de Estados Iberoamericanos para

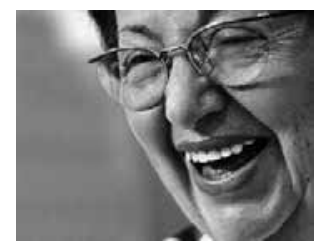
a Educação (OEI) reconhecerem as contribuições da educadora para a educação. 